\title{
СТАНОВЛЕННЯ МІЖНАРОДНО-ПРАВОВОЇ ОСНОВИ ЗАСТОСУВАННЯ ПОКАРАННЯ У ВИДІ ШТРАФУ ДО НЕПОВНОЛІТНІХ
}

\author{
МИЦЬКА Олександр Іванович - викладач циклу загальноправових \\ дисциплін Дніпровського центру підвищення кваліфікації персоналу Державної \\ кримінально-виконавчої служби України
}

DOI:10.32782/LAW.2019.3.20

УДК 342.2.01:343.91 (477)

У статті наголошено на тому, що зусиллями Організачія Об’єднаних Начій та Ради Европи протягом 2-ї половини ХХ століття були створені стандарти покарання неповнолітніх за вчинення того чи іншого кримінально караного діяння. Міжнародне і європейсъке співтовариство кодифікувало створені стандарти у багатьох джерелах міжнародного права.

Доведено, що міжнародно-правові стандарти у сфері застосування штрафу до неповнолітніх спрямовані на те, щоб кожна дитина, яка, як вважається, порушила кримінальне законодавство чи звинувачується в його порушенні, мала відповідні гарантї, що обумовлені особливим ставленням суспільства до изіності дитинства; забезпечувалась повна повага ї особистого життя на всіх стадіях розгляду.

Робиться висновок, що міжнародні нормативно-правові акти таких організацій, як ООН та Ради Европи, які мають як загальнообов'язковий, так і рекомендаиійний характер, використовуючи кримінально-правову модель застосування покарання стверджується, шо міжнародна правова спільнота прийняла ряд документів, у яких чітко простежується тендениія гуманізаиї кримінально-правового реагування до неповнолітніх осіб, які порушили кримінальний закон. Складовою иієї тендениій $\epsilon$ широке застосування штрафуу до неповнолітніх, який є громадсъкою санкиією не пов'язаною з ізоляиією від суспільства.

Ключові слова: неповнолітній, покарання, штраф, міжнародні стандарти, поводження.

ШІтраф як вид кримінального покарання неповнолітніх за всі часи свого існування привертав увагу як зарубіжних, так і вітчизняних учених, на сьогодні ця тематика також залишається актуальною. Ще наприкінці XIX - на початку XX ст. почались робитись спроби пошуку альтернатив такому виду покарання, як позбавлення волі.

Не буде новиною, що національне законодавство у сфері застосування покарання до неповнолітніх має відповідати вимогам міжнародних стандартів. 3 цього приводу відмічають В.М. Бурдін та А.М. Палюх, що законодавство України про кримінальну відповідальність у ряді випадків не відповідає положенням зазначених у міжнародно-правових актах, потребує узгодження з ними, містить низку недоліків (колізій, прогалин), які негативно позначаються на правозастосовний практиці [3, с. 108].

У програмі I Міжнародного конгресу обговорювались проблемі питання «Чи є можливість замінити короткострокове позбавлення волі і неплатіж штрафу посиленими роботами без позбавлення волі?» [16, с.173], навколо цього питання виник неабиякий інтерес та точились жваві дискусії, що були перенесені на наступні конгреси. Наступним кроком у розвитку альтернатив позбавленню волі став III Міжнародний тюремний конгрес, який відбувався в Римі, на ньому торкнулися питання запровадження альтернатив короткостроковому тюремному ув'язненню до пропозицій увійшли: штраф; судова догана; примусові роботи без позбавлення волі; обмеження у виборі місця проживання [16, с.174].

На Конгресі, що відбувався в Лондоні під впливом англійських делегатів, була винесена 
резолюція, яка передбачала альтернативи, які були уже введені англійським законодавством це : штраф; система піклувального нагляду.

IV Конгрес ООН з попередження злочинності і поводження із засудженими визначив, що назріла необхідність пошуку необхідних альтернатив позбавленню волі і заходів спрямованих і заходів повернення правопорушників до суспільно корисної діяльності і прийняв резолюцію № 8, яка рекомендувала країнам - членам ООН розширити застосування альтернативних тюремному ув’язненню санкцій і проводити інтенсивний пошук надійних видів альтернатив [16, с.174].

Зусиллями Організація Об’єднаних Націй та Ради Европи протягом 2-ї половини XX століття були створені стандарти покарання неповнолітніх за вчинення того чи іншого кримінально караного діяння. Міжнародне i європейське співтовариство кодифікувало створені стандарти у багатьох джерелах міжнародного права.

Доктринальні джерела міжнародного права визначають таку класифікацію міжнародних стандартів: а масштабом дії (універсальні й регіональні); за спеціалізацією (стандарти загального і спеціального характеру); за обов'язковістю для держав-учасниць (обов'язкові й стандарти-рекомендації).

3 приводу класифікації міжнародних стандартів необхідно погодитись 3 думкою вченої О.О. Бублік яка додає до цієї класифікації ще один поділ - за джерелами походження, підкреслюючи види міжнародних договорів (пакти, конвенції) а також норми і принципи, прийняті урядовими і неурядовими організаціями [2, с. 148].

Досліджуючи альтернативні позбавленню волі покарання, Е.В. Хромих виділяє такі дві групи міжнародних стандартів, умовно поділяючи їх за способом регулювання на такі: які регулюють застосування позбавлення волі; які регулюють застосування покарання, i інших заходів, альтернативних позбавленню волі (не пов'язаного з позбавленням волі - О.М.) [15, c. 68].

E.C. Назимко, вивчаючи інститут неповнолітніх у кримінальному праві України через призму діючих джерел міжнародного права відносить Декларацію прав дитини 1959 р., Мінімальні стандартні правила Організації
Об’єднаних Націй, що стосуються відправлення правосуддя щодо неповнолітніх (Пекінські правила) 1985 р., Конвенція про права дитини від 20 листопада 1989 р., Мінімальні стандартні правила Організації Об’єднаних Націй по відношенню до заходів, які не пов'язані із тюремним ув'язненням 1990 р., Правила Організації Об'єднаних Націй, які стосуються захисту неповнолітніх, позбавлених волі 1990 р., Керівні принципи Організації Об'єднаних Націй для попередження злочинності серед неповнолітніх (Ер-Ріядські керівні принципи) 1990 р., Керівні принципи ООН по відношенню до дій в інтересах дітей у системі кримінального правосуддя (додаток до відповідної резолюції Економічної та Соціальної Ради ООН від 21 липня 1997 р.). Рекомендацію № R (2008) 11 Комітету Міністрів державам-членам Ради Европи «Про Европейські правила по відношенню до неповнолітніх правопорушників, засуджених до покарань та заходів кримінально-правового характеру» [9, с. 226-227]. Н.ᄉ. Березовська, приводячи аналіз міжнародно-правових документів, які стосуються правового статусу неповнолітніх злочинців, поділяє їх на два види загального і спеціального характеру [1, с. 128].

Загальними видами є Декларацію прав дитини 1924 р., Декларацію прав дитини 1959, Конвенцію про права дитини 1989 р. До спеціальних - Мінімальні стандартні правила Організації Об'єднаних Націй, що стосуються відправлення правосуддя стосовно неповнолітніх (Пекінські правила) 1985 р., Керівні принципи Організації Об'єднаних Націй для попередження злочинності серед неповнолітніх (Ер-Ріядські керівні принципи) 1990 р., Мінімальні стандартні правила ООН щодо заходів, не пов'язаних із тюремним ув’язненням (Токійські правила) 1990 р. та ін., які закріплюють положення щодо засуджених, у тому числі й неповнолітніх.

Фундаментальним міжнародно-правовим актом ООН, що проголошуе права і свободи дитини є Декларація прав дитини 1959 року. У преамбулі Декларації вказується, що дитина через їі розумову незрілість потребує спеціальної охорони і турботи, включаючи належний правовий захист [4].

Норми Декларації знайшли своє підтвердження у Конвенції ООН про права дитини, 


\section{Кримінальне право, кримінальний процес та криміналістика}

яка ще має назву «Світова Конституція прав дитини», вона є першим і основним документом обов'язкового характеру. У Конвенції ООН про права дитини 1989 р. проголошено, що дитина має бути повністю підготовлена до самостійного життя в суспільстві та вихована в дусі ідеалів проголошених у Статуті ООН.

у статті 40 Конвенції закріплено, що Держави-учасниці визнають право кожної дитини, яка, як вважається, порушила кримінальне законодавство, звинувачується або визнається винною в його порушенні, на таке поводження, що сприяє розвиткові у дитини почуття гідності і значущості, зміцнюе в ній повагу до прав людини й основних свобод інших та при якому враховуються вік дитини і бажаність сприяння іï реінтеграції та виконання нею корисної ролі в суспільстві.

3 цією метою і беручи до уваги відповідні положення міжнародних документів, держави-учасниці, зокрема, забезпечують, щоб: жодна дитина не вважалася порушником кримінального законодавства, не була звинувачена та визнана винною в його порушенні через дію чи бездіяльність, які не були заборонені національним і міжнародним правом на час їх здійснення; кожна дитина, яка, як вважається, порушила кримінальне законодавство чи звинувачується в його порушенні, мала принаймні такі гарантії: презумпцію невинуватості, поки іï вина не буде доведена згідно із законом; негайне і безпосередне інформування іï про звинувачення проти неї, а у випадку необхідності, через ії батьків чи законних опікунів, та одержання правової й іншої необхідної допомоги при підготовці та здійсненні свого захисту; невідкладне прийняття рішення 3 розглядуваного питання компетентним, незалежним і безстороннім органом чи судовим органом у ході справедливого слухання згідно із законом у присутності адвоката чи іншої відповідної особи i, якщо це не вважається таким, що суперечить найкращим інтересам дитини, зокрема, 3 урахуванням іï віку чи становища іï батьків або законних опікунів; свобода від примусу щодо наданих свідчень чи визнання вини; вивчення показань свідків звинувачення або самостійно, або за допомогою інших осіб та забезпечення рівноправної участі свідків захисту та вивчення їх свідчень; якщо вважається, що дитина порушила кри- мінальне законодавство, повторний розгляд вищим компетентним, незалежним і безстороннім органом чи судовим органом згідно із законом відповідного рішення та будь-яких вжитих у цьому зв'язку заходів; безплатна допомога перекладача, якщо дитина не розуміє використовуваної мови чи не розмовляє нею; повна повага її особистого життя на всіх стадіях розгляду.

Держави-учасниці прагнуть сприяти створенню законів, процедур, органів і установ, що мають безпосереднє відношення до дітей, які, як вважається, порушили кримінальне законодавство, звинувачуються чи визнаються винними в його порушенні, і зокрема: встановленню мінімального віку, нижче якого діти вважаються нездатними порушити кримінальне законодавство; у випадку необхідності і бажаності вжиттю заходів щодо поводження $з$ такими дітьми без використання судового розгляду за умов повного додержання прав людини і правових гарантій.

Необхідна наявність таких різних заходів, як догляд, положення про опіку і нагляд, консультативні послуги, призначення випробного строку виховання, програми навчання i професійної підготовки, та інших форм догляду, що замінюють догляд в установах, з метою забезпечення такого поводження $з$ дитиною, яке забезпечувало 6 іï добробут і відповідало її становищу та характеру злочину [4].

Досліджуючи положення Конвенції ООН «Про права дитини», Ю.В. Єгорова зазначає, виходячи 3 того, що неповнолітні особи 6 більш уразливою категорію суб'єктів злочину, рекомендується більш лояльно підходити до здійснення правосуддя по відношенню до неповнолітніх [11, с.114]. На наш погляд, доцільно звернутися до такого міжнародного документа Мінімальні стандартні правила ООН, які стосуються відправлення правосуддя щодо неповнолітніх (Пекінські правила). Правила закріплюють стандарти поводження 3 неповнолітніми правопорушниками на всіх стадіях здійснення правосуддя, включаючи відбування покарання. При цьому в правилах передбачено норми на необхідність вдосконалення системи правосуддя до неповнолітніх.

Ст.17.1 Пекінських правил визначає перелік принципів якими повинен керуватись компетентний орган при засновуванні заходів 
кримінально-правового впливу, до переліку входять наступні принципи: заходи впливу завжди повинні бути співрозмірними не тільки з обставинами і тяжкістю правопорушень, але і з становищем та потребами неповнолітнього, а також із потребами суспільства; рішення про обмеження особистої волі неповнолітнього повинно прийматися тільки після ретельного розгляду питання, і обмеження повинно бути по можливості зведено до мінімуму; неповнолітнього правопорушника не слід позбавляти особистої волі, якщо тільки він не визнаний винним у вчиненні серйозного діяння [7].

Як стверджує E.С. Назимко, юридичні і філософські цілі покарання, як «відплата по заслугах» та «загальне попередження» не можуть оминати та не враховувати такої фундомантальної вимоги при застосуванні покарання за вчинення злочину, як «інтереси суспільства». Міжнародні стандарти застосування покарання до неповнолітніх і не можуть остаточно поставити «найвищі інтереси» неповнолітнього правопорушника вище за інтересів суспільства («інтереси справедливості»). Ця позиція підтверджується тим, що тяжкість вчиненого злочину та інтереси суспільства є взаємопов'язаними складовими, які зумовлюють винесення того чи іншого вироку неповнолітньому правопорушникові [6, с. 26].

3 метою недопущення ізоляції неповнолітнього від суспільства ст. 18 Пекінських правил закріплює широкий комплекс заходів впливу, до яких належать: 1) постанови про опіку, керівництво і нагляд; 2) пробація;3) постанови про роботу на користь громади; 4) фінансові покарання, компенсація і реституція; 5) постанови про прийняття проміжних й інших заходів; 6) постанови про участь у груповій психотерапії й інших подібних заходах; 7) постанови, що стосуються передачі на виховання, місця проживання або інших виховних заходів; 8) інші відповідні постанови [7]. Зазначений перелік цих заходів дуже широкий, як ми бачимо, йому притаманні і фінансові покарання.

Універсальним міжнародним документом, який також встановлює стандарти поводження 3 неповнолітніми, які вчинили злочин, 6 Мінімальні стандартні правила ООН щодо заходів, не пов'язаних з тюремним ув'язненням
(Токійські правила). Основною метою цих правил рекомендувати державам-членам розробити санкції, не пов'язані 3 тюремним ув'язненням і забезпечення можливості для максимального скорочення тюремного ув'язнення [8].

Правилом 3.2. Токійських правил передбачено, що заходи, не пов'язані з тюремним ув'язненням неповнолітніх, застосовуються з у рахуванням таких обставин: характер та ступінь тяжкості скоєного правопорушення; особливості та біографія правопорушника; мета вироку і права жертви [8].

Важливо звернути увагу й на вимоги адекватності застосування кримінально-правових заходів до неповнолітніх, а саме те, що суди мають враховувати фізичній, психічній, соціальній вразливості неповнолітніх.

Токійські правила визначають широкий спектр санкцій, які можуть бути альтернативами тюремному ув'язненню (ст. 8.2): усні санкції, такі, як зауваження, догана і попередження; умовне звільнення від відповідальності; покарання, пов'язані з поразкою в громадських правах; економічні санкції і грошові покарання, такі, як штрафи; конфіскація або постанова про експропріацію; компенсація жертві; умовне покарання або покарання з відстрочкою; умовне звільнення і судовий нагляд; ухвала про виконання суспільно корисних робіт; направлення до виправної установи 3 обов'язковою щоденною присутністю; домашній арешт; будь-який інший вид поводження, не пов'язаний з тюремним ув'язненням; поєднання зазначених заходів [8].

Як бачимо, зазначеними Правилами встановлено, що штрафи можуть бути разовими та поденними. Такі санкції передбачені у кримінальному законодавстві окремих країн континентальної правової сім'ї. Так, у КК ФРН покарання чітко розмежовані на основні і додаткові. До основних покарань належать: позбавлення волі; грошовий штраф; майновий штраф [10, с. 84], це ще раз показує те що штраф може бути не тільки грошовим, а і майновим покаранням.

Одним із розповсюджених майнових покарань за КК Франції $\varepsilon$ штраф, який поділяється на звичайний грошовий штраф та штрафо-дні [5]. Відносно системи кримінальних покарань в Україні штраф є найменш 


\section{Кримінальне право, кримінальний процес та криміналістика}

суворим покаранням для неповнолітніх.Актуальність цього покарання в системі кримінального правосуддя України полягає в тому, що воно може бути направлено не тільки на грошові кошти, але і на майно, яке є особистою власністю правопорушника.

Поряд з універсальними не меншого значення мають і регіональні правові стандарти, прийняті Радою Европи. Окремі положення стосовно альтернатив тюремному ув'язненню, а штрафу зокрема, міститься в Резолюції міністрів Ради Европи «Про деякі заходи покарання, альтернативні тюремному ув'язненню»10. 03.1976 р., цей документ має загальний характер і не поширюється винятково на неповнолітніх. Підпункт b вищезгаданого правового акта закріплює забезпечення широкого застосування штрафу з урахуванням матеріального становища суб'єкта відповідальності, притому отримання штрафу передбачає необхідність, де це можливо розумної мінімізації тюремного ув'язнення [12]. Ще одним актом, присвяченим альтернативам тюремному ув'язненню, затверджені Комітетом Міністрів Ради Европи 19.10.1992 р. «Европейські правила щодо застосування громадських санкцій та заходів». У преамбулі цих правил визначено, що вони стосуються всіх санкцій і заходів, виконання яких не пов'язано з позбавленням волі. Тим не менше, заходи, які спеціально пов'язані 3 неповнолітніми, не охоплені цими правилами [13]. Правило 27, яке закріплює, що громадські санкції та заходи повинні застосовуватись таким чином, щоб не загострювати ій хворобливий характер. Правило 86 передбачає, що рішення про скасування громадської санкції та заходу не повинно обов'язково призводити до ухвали рішення про позбавлення волі. У цьому випадку у разі призначення штрафу 3 розстрочкою виплати певними частинами при можливій індексації сума платежу не повинна перевищувати реального розміру на момент призначення його судом [14, с.52, 53]. Проаналізувавши положення цього нормативного акта, ми можемо сказати що він спрямований на мінімізацію використання ізоляції від суспільства та широкого використання принципу економії кримінальної репресії, посилення громадських заходів та санкцій; забезпечення більшої гнучкості застосування альтернативних санкцій до непо- внолітніх, які вступили в конфлікт із законом; застосування громадських санкцій та заходів щодо неповнолітніх.

Таким чином, проаналізувавши міжнародні нормативно-правові акти таких організацій, як ООН та Ради Европи, які мають як загальнообов' язковий, так і рекомендаційний характер, використовуючи кримінально правову модель застосування покарання, можна з впевненістю сказати, що міжнародна правова спільнота прийняла ряд документів, у яких чітко простежується тенденція гуманізації кримінально-правового реагування до неповнолітніх осіб, які порушили кримінальний закон. Складовою цієї тенденції $є$ широке застосування штрафу до неповнолітніх, який 6 громадською санкцією, не пов'язаною з ізоляцією від суспільства.

\section{入iтература}

1. Березовська Н.ᄉ. Покарання, пов'язані 3 виправно-трудовим впливом, що застосовуються до неповнолітніх: дисертація на здобуття наукового ступеня кандидата юридичних наук зі спеціальності 12.00.08 - кримінальне право та кримінологія; кримінально-виконавче право. Одеса: Одеська національна юридична академія, 2010. - 243 с.

2. Бублік О.О. Праця засуджених до позбавлення волі: правова регламентаці та кримінально-виконавча практика : дисертація на здобуття наукового ступеня кандидата юридичних наук за спеціальністю 12.00.08 - Кримінальне право та кримінологія; кримінально-виконавче право. Запоріжжя : Класичний приватний університет, 2016. 226 с.

3. Єгорова Ю. В. Умовні види звільнення неповнолітніх від покарання та його відбування у кримінальному праві України: дисертація на здобуття наукового ступеня кандидата юридичних наук за спеціальністю 12.00.08 - кримінальне право та кримінологія; кримінально-виконавче право. Донецьк: Донецький юридичний інститут МВС України, 2015. 249 с.

4. Конвенція про права дитини від 20 листопада 1989 p. URL: http://zakon4.rada.gov.ua/ laws/show/995 021.

5. Крикунов О.В. Покарання, що обмежують майнові права, за Кримінальним кодексом Франції URL: http://evnuir.univer.lutsk.ua/ bitstream/.../1/Krykunov\%20O..pdf . 
6. Литвинов О.М., Назимко Е.С. Міжнародні та європейські стандарти застосування покарання до неповнолітніх: науковий нарис; за заг. ред. д.ю.н., проф. О.М. Аитвинова ; Донецький юридичний інститут МВС України; Кримінологічна асоціація України. - К. :ВД «Дакор», 2015. 76 с.

7. Минимальные стандартные правила Организации Объединенных Наций, касающиеся отправления правосудия в отношении несовершеннолетних («Пекинские правила») URL: http://zakon4.rada.gov.ua/laws/ show/995_211/print1398971132987606.

8. Мінімальні стандартні правила Організації Об'єднаних Націй у відношенні заходів, не пов'язаних з тюремним ув'язненням (Токійські правила) URL: http://zakon.rada.gov.ua/ laws/show/995_907.

9. Назимко E .С. Теоретико-прикладні засади становлення та розвитку інституту покарання неповнолітніх у кримінальному праві України : дисертація на здобуття наукового ступеня доктора юридичних наук за спеціальністю 12.00.08 - Кримінальне право та кримінологія; кримінально-виконавче право. Х.: Харківський національний університет внутрішніх справ, 2016. 565с.

10. Назимко E.С. Зарубіжний досвід кримінально-правової регламентації інституту покарання неповнолітніх : монографія. Сгор Сергійович Назимко, вступне слово та загальна редакція д.ю.н., проф. О.М. Аитвинова; Донецький юридичний інститут МВС України, Кримінологічна асоціація України. К.: КНТ, 2015. 368 с.

11. Назимко E.С., Сгорова Ю.В. Умовне звільнення неповнолітніх від покарання та його відбування у кримінальному праві України (генеза, види, подальший розвиток): монографія. Київ : ВД «Дакор», 2016. 200 с.

12. Резолюція № (76) 10 про деякі заходи покарання, альтернативні позбавленню волі URL: https://zakon.rada.gov.ua/laws/ show/994_050 - Назва з екрана

13. Рекомендація № R (92) 16 Комітету міністрів державам-членам про Европейські правила щодо загальних санкцій та заходів URL: http://kvs.gov.ua/rekomendacia.pdf.
The article notes that the efforts of the United Nations and the Council of Europe during the 2nd half of the 20th century created standards for punishing minors for committing a criminal offense. The international and European community codified standards in many sources of international law.

It has been proved that international legal standards in the field of the application of fines to minors are aimed at ensuring that every child who is considered to have violated criminal law or is accused of violating it has appropriate guarantees due to the special attitude of society to the value of childhood; full respect for his personal life at all stages of the proceedings was ensured.

It is concluded that the international legal acts of organizations such as the UN and the Council of Europe are both generally binding and recommendatory in nature, using the criminal law model of the application of punishment, it is argued that the international legal community has adopted a number of documents that clearly trace the trend towards the humanization of criminal legal response of minors who violate the criminal law. A component of this trend is the widespread application of the fine to minors, which is a public sanction not related to isolation from society.

Key words: minor, punishment, fine, international standards of treatment.

14. Уткина C.С. Уголовное наказание в виде штрафа. Томск: Изд-во Том.ун-та, 2004. 166 с.

15. Хромых Е.В Альтернативные лишению свободи уголовные наказания: теория и практика назначения и исполнения: диссертация на соискание ученой степени кандидата юридических наук по специальности 12.00.08 Уголовное право и криминология; уголовноисполнительное право. Ростов: Ростовский юридический институт, 2005. 231с.

16. Черкасов С. В. Кримінологічна концепція альтернативних мір покарання: дисертація на здобуття наукового ступеня кандидата юридичних наук за спеціальністю 12.00.08 - Кримінальне право та кримінологія; кримінально-виконавче право. Одеса: Одеська національна юридична академія, 2004. 225 с. 